Historic, Archive Document

Do not assume content reflects current scientific knowledge, policies, or practices. 

Kescrue

A) 99.9

F7632U

Carnivora Food Habits and Habitat Use in Ponderosa Pine Forests

Frank J. Turkowski

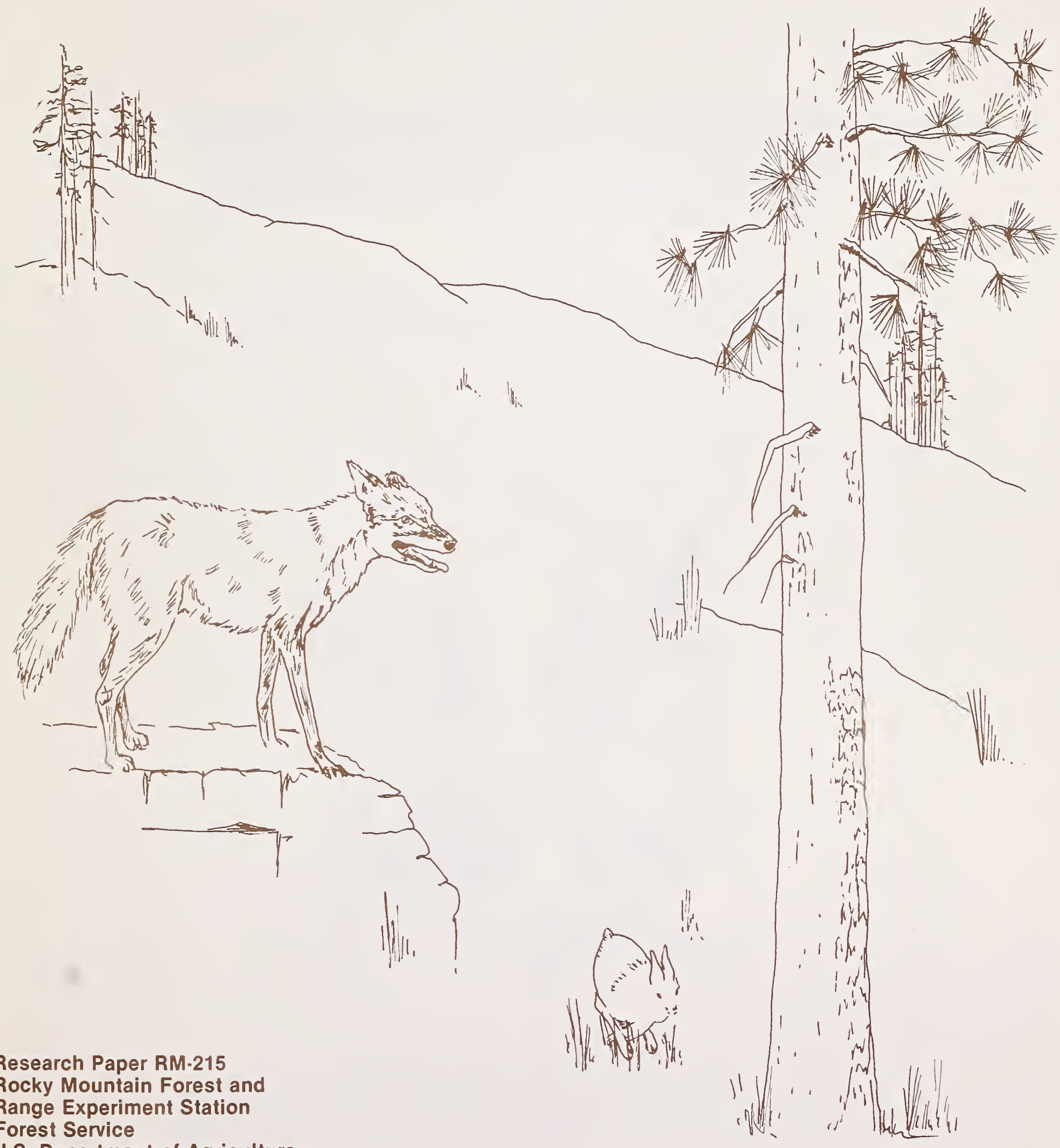

U.S. Department of Agriculture 


\section{Abstract}

Major food items of carnivores on the Beaver Creek Watershed (with percentage of scats in which each was found) were mammals $50 \%$, birds $6 \%$, reptiles $3 \%$, arthropods $37 \%$, and plants $60 \%$. Although habitat manipulation influenced carnivore use of the treated watersheds, the modifications were not harmful to most carnivore species.

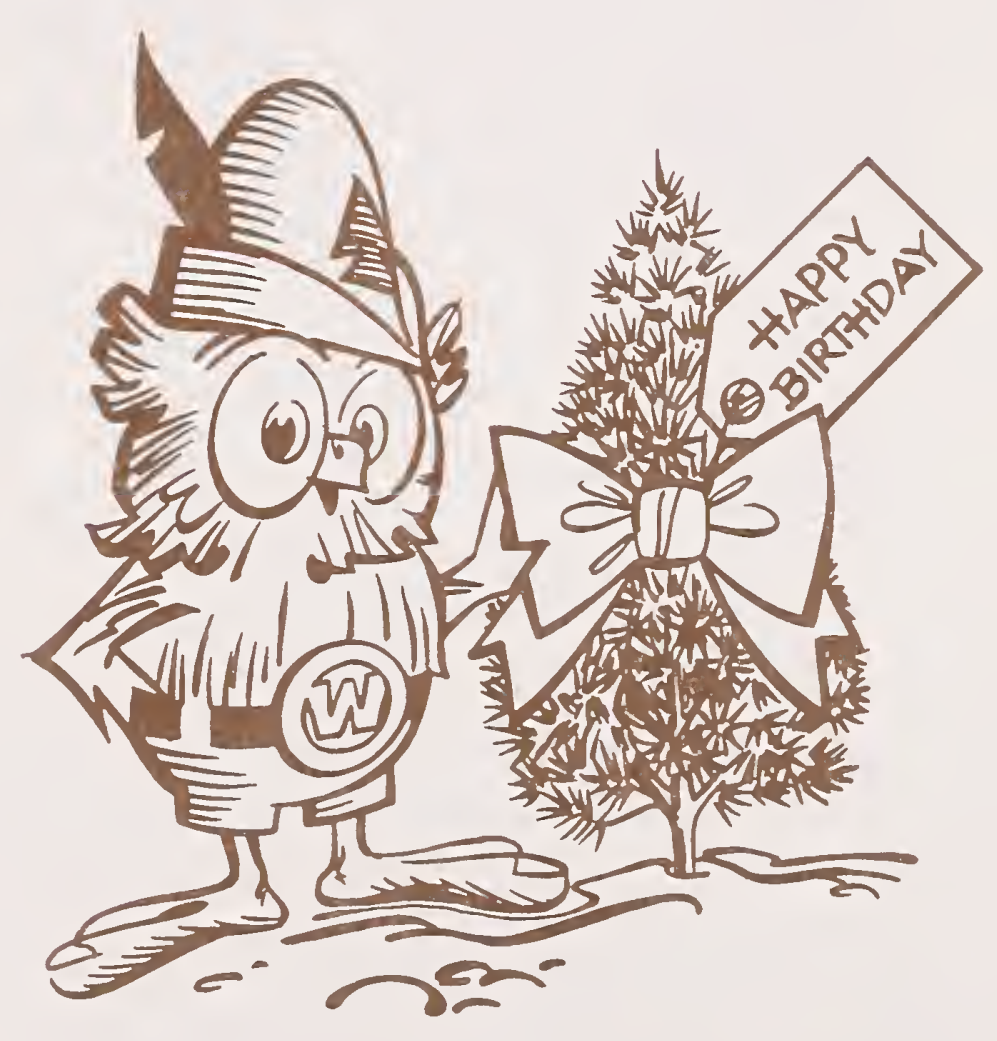

Plant a tree! Mark the 75th birthday of the Forest Service by giving a living gift to future generations. 


\title{
240 \\ Carnivora Food Habits and Habitat Use in Ponderosa Pine Forests .
}

\author{
Frank J. Turkowski, Wildlife Research Biologist \\ Rocky Mountain Forest and Range Experiment Station'
}




\section{Contents}

Page

Management Implications $\ldots \ldots \ldots \ldots \ldots \ldots \ldots \ldots \ldots \ldots \ldots \ldots \ldots \ldots \ldots \ldots \ldots \ldots \ldots$

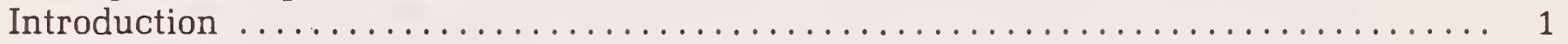

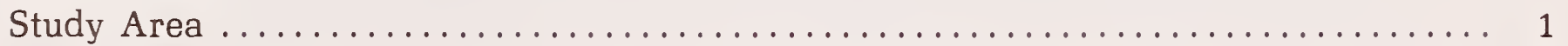

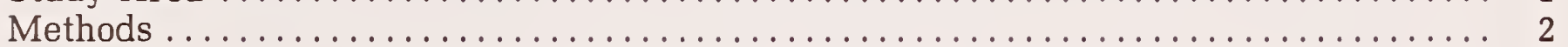

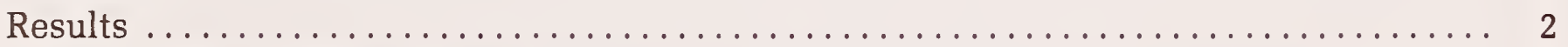

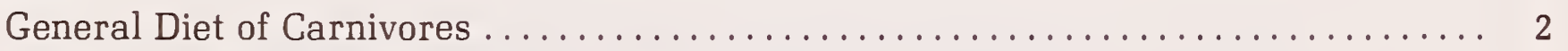

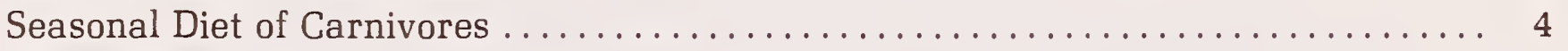

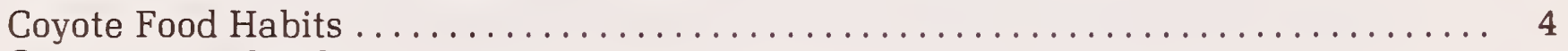

Gray Fox Food Habits . . . . . . . . . . . . . . . . . . . . . . . . 5

Bobcat Food Habits......................................... 5

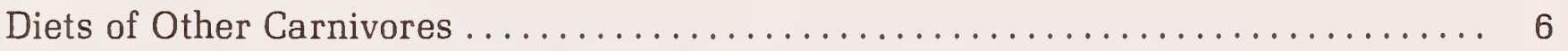

Use of Beaver Creek Areas by Carnivores .......................... 6

Winter Use of Watersheds by Carnivores .......................... 6

Discussion ............................................. 7

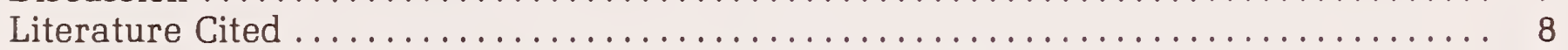

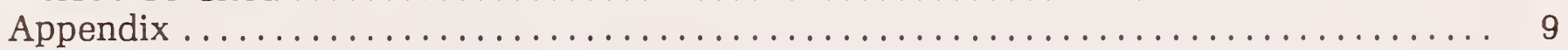




\title{
Carnivora Food Habits and Habitat Use in Ponderosa Pine Forests
}

\author{
Frank J. Turkowski
}

\section{Management Implications}

Habitat manipulations alter the food supply of carnivores and thereby influence their populations. Earlier studies have documented that carnivores can be influenced by habitat conditions and prey abundance (Lauckhart 1956, McCord 1974, Rollings 1945, Wood 1952, Wood et al. 1958). Actions that increase grasses and forbs are beneficial to most prey populations, especially if downed trees and slash are left for cover (Chew et al. 1959; Cook 1959; Lawrence 1966; LoBue and Darnell 1959; McCulloch 1962, 1963, 1965, 1966; Reynolds 1964; Turkowski and Reynolds 1970; Turkowski and Watkins 1976). In such instances, predators would ultimately benefit, because their food sources are increased.

Altered habitat conditions also could directly benefit predators by providing more denning sites and cover for stalking prey, and by otherwise improving habitat conditions.

Generally, it appears that although habitat manipulations in ponderosa pine habitat influenced predator food habits and behavior on the Beaver Creek area, the changes are not harmful to most carnivore species, as seen by their use of the treated watersheds as much as the untreated stands of ponderosa pine.

\section{Introduction}

At least 12 species of Carnivora including coyotes, gray foxes, bobcats, skunks, raccoons, weasels, and badgers inhabit most ponderosa pine forest areas in the southwestern United States (Hall and Kelson 1959), yet little is known about the role of these predators in this ecosystem. (Scientific names of flora and fauna referred to in this paper are listed in the appendix.) Much of this habitat is being modified by watershedmanagement techniques; and, though primary consumers are known to be influenced by vegetation manipulation, there is limited knowledge of how these effects are manifested through food chains or food webs to the predators, especially in forest habitats.

\section{Study Area}

The Beaver Creek experimental watersheds are on the Coconino National Forest near Happy Jack, Ariz. (fig. 1). Elevations vary from 6,800 to 8,000 feet. Slopes are moderately steep and well drained. Soils are mostly silty clays and silty clay loams. January is the coldest month. The average temperature is $45^{\circ} \mathrm{F}$. The average annual precipitation is 25 inches. Summer moisture averages 5 inches, mostly during July and August. Winter moisture is from snow.

Ponderosa pine is the dominant tree. Gambel oak, junipers, New Mexican locust, and aspen are also found in some areas.

Understory plants include Arizona fescue, blue grama, mountain muhly, Junegrass, geranium, peavine, and clover.
The Beaver Creek Project was established during the late 1950's to evaluate watershed treatments. The influences are evaluated by their effects upon water yield, sedimentation, flood control, timber production, forage, wildlife, and esthetics. Pilot treatments in ponderosa pine forests are being tested on watersheds of up to 2,036 acres. There is permanent water on most of the watersheds.

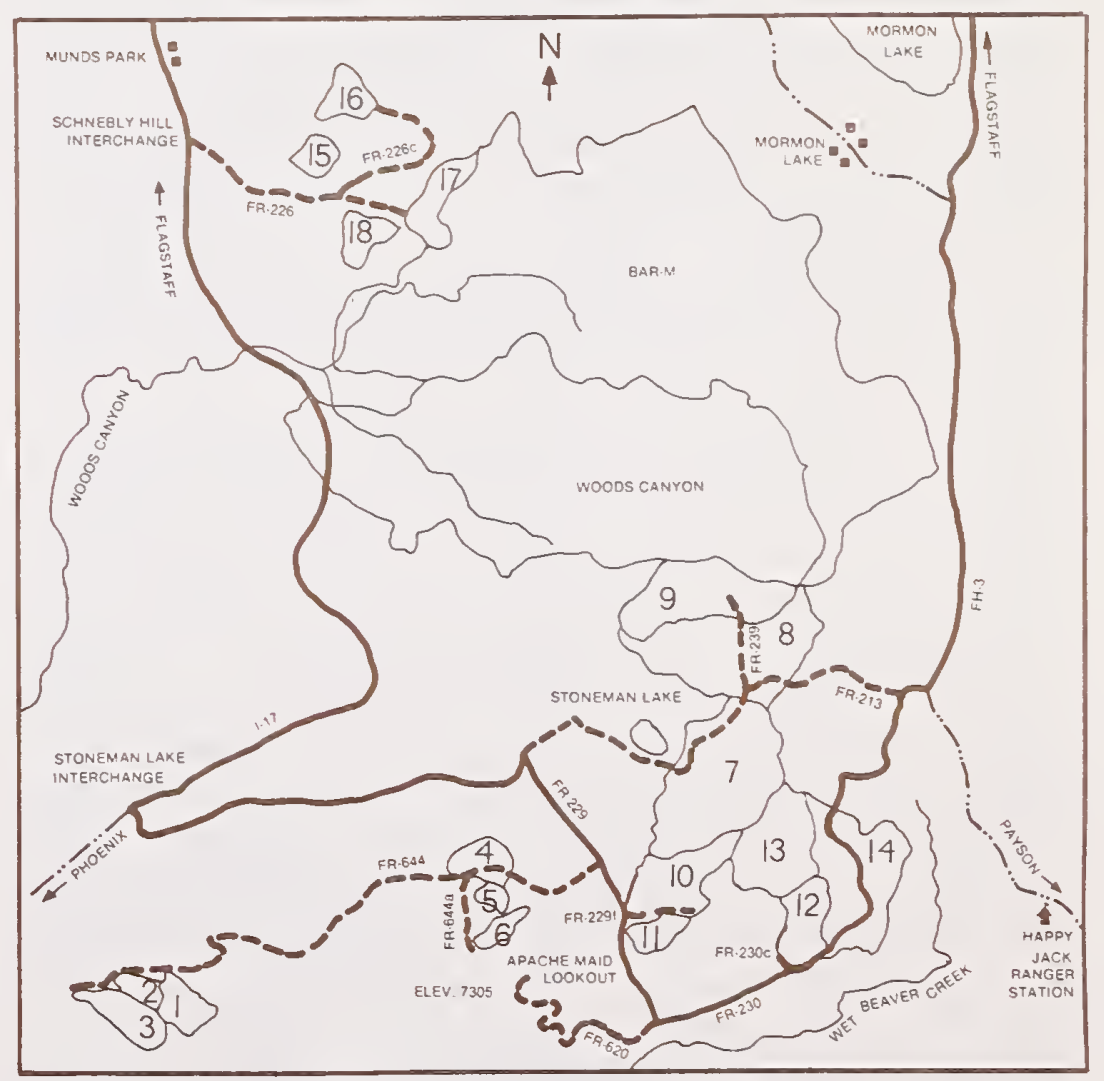

Figure 1. - The Beaver Creek experimental watersheds. Individ. ual watersheds are outlined and numbered. 
Specific land-management systems investigated in this study were overstory clearcut and slash windrowed (watershed (WS) 12); one-third overstory clearcut with remainder thinned to 80 square feet of basal area per acre (WS 14); overstory thinned to 30 square feet of basal area per acre (WS 17); and overstory selectively cut to a silvicultural standard (WS 8). Additional activities were assessed on an area with overstory representing natural conditions (WS 13), and on an area with overstory to be cut for wildlife habitat improvement (WS 10) (fig. 1). Check areas adjacent to all of the above plots were also assessed.

Carnivores known to inhabit the study area were coyotes, gray foxes, bobcats, mountain lions, black bears, striped skunks, badgers, long-tailed weasels, and raccoons.

\section{Methods}

To obtain information on food habits and species composition, carnivore droppings were collected each month by driving or walking over a prescribed route of 21 miles of unpaved roads. Each month from March 1972 to June 1974 was represented at least once by fecal samples. The route included 12.5 miles in the five treated watersheds and one control watershed, and 8.5 miles in untreated areas adjacent to the watersheds. A total of 200 miles was driven over study areas during months without snow, and 30 miles were driven during months with snowfall. Scats were placed in small plastic bags and labeled according to date, location, and species. Identification of most scats was made by odor, size, and shape (Murie 1954) and by associated tracks and other markings.

Coyotes, gray foxes, and bobcats contributed over $60 \%$ of the total number of analyzed scats. Track counts also indicated that these species were the most abundant carnivores. Scats of coyotes, gray foxes, bobcats, and mountain lions were easy to distinguish if the scats kept their original shape. Many droppings of the other predators, especially scats containing large percentages of juniper berries or insect remains, were amorphous and often indistinguishable. Additional identified scats or stomachs were taken from livetrapped or road-killed small carnivores. This technique supplied most of the striped skunk and raccoon samples. Scats included in the food habit analysis of all carnivores were also obtained from near water tanks and coincidental to work off the roads.

Fecal samples were stored and analyzed by the methods used by Gier (1957), Scott (1941, 1943), Wood (1954), Murie (1946), and others for carnivore scat and alimentary tract analysis. Scats were washed, then placed in a large petri dish of water and floated apart. Food items were separated into groups of bones, teeth, scales, feathers, hair, and invertebrate remains. Feathers, bones, and hair were dried to bring out colors and facilitate comparisons with study skins and reference skeletons. Data from each dropping were entered on forms, then sorted for various analyses.
Fecal analysis has been determined to be a reliable method of determining carnivore food habits. For example, Wood (1954) reported that stomachs, intestines, and scats were similar in frequencies of food for several fur-bearers in Texas. Similar agreement was evident in gray fox habits as reported by Turkowski (1969).

Scat analyses provided general information on food habits of coyotes, bobcats, and smaller predators and allowed for comparisons of food between treated and nontreated areas by the frequency of occurrence of the prey species. Presence of the various food items was expressed in percentages of the total number of times each occurred in all the scats. Many foods were only identified into general categories. However, no item could have greater potential for scoring occurrences than another item with which it was contrasted in the same scat. This treatment included the undetermined items where foods could not be identified beyond a general grouping.

\section{Results}

\section{General Diet of Carnivores}

A total of 367 carnivore droppings were analyzed. The percent of scats containing food items in each of the major taxonomic categories is listed seasonally by species in table 1. Also presented is a summary of all the items within the major categories that were consumed by all the predators combined. An examination of this combined diet provides some knowledge of energy flow in ponderosa pine forests. Frequency of occurrence of major groups in the combined carnivore diet was: mammals 49.9 , birds 6.3 , reptiles 3.0 , arthropods 37.3 , and plants 60.5 . In this total diet, arthropods were an important contribution, and many scats contained the remains of these invertebrates exclusively. Juniper berries were also consumed frequently and were found in $48.8 \%$ of all the scats, though some carnivore species relied on them more than this combined figure suggests.

Among the mammals used as foods, ungulates were frequent items for the study period. Deer were in $11.3 \%$ of the scats and elk were in $6.2 \%$. Some of the deer and antelope, especially those eaten during the winter, were probably taken as carrion since some wounded animals were no doubt present after the hunting seasons. Cattle also contributed to the ungulate food category. The rodents most frequently in the carnivore diet were meadow mice and white-footed mice. Abert squirrels were found in $4.9 \%$ of the scats and rock squirrels were in $3.2 \%$ of the droppings. Reptiles were a minor percentage of the overall diet. The birds most frequently found were small perching species and the remains of a few turkeys. The reptiles found were lizards and snakes. Frog bones were detected in two scats, and fish scales were found in three droppings. 


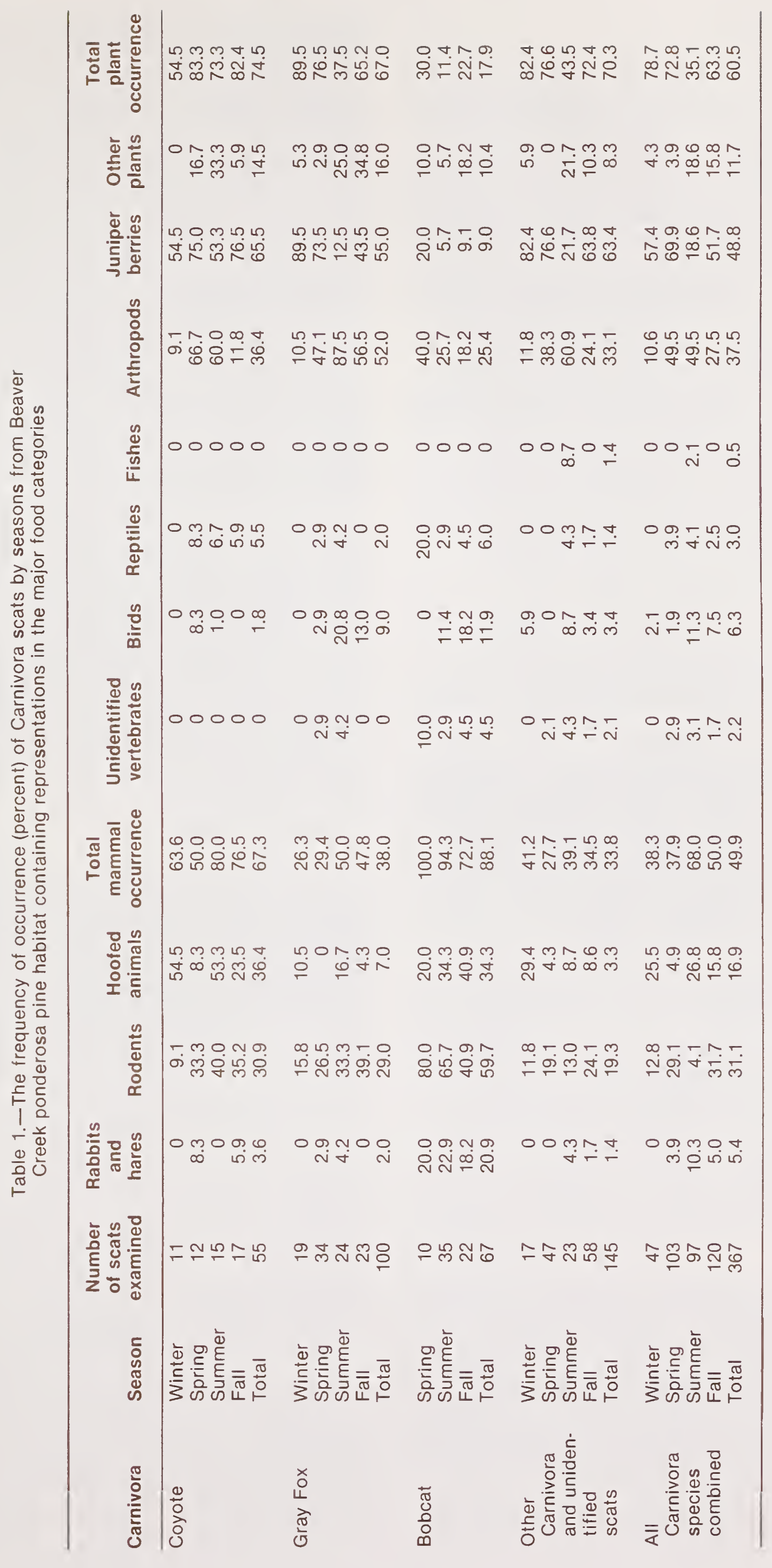




\section{Seasonal Diet of Carnivores}

Examination of the food items consumed by all predators by seasons indicated how changing habitat conditions related to use of prey animal and plant energy sources. The percentage of mammals in the total predator diet was greatest from June to August and least from December to May. This correlated with prey availability as evidenced by the trapping success for small mammals during these periods (Goodwin 1975). Also, many small rodents hibernated or were inactive from October through March, which partly accounts for their absence in the diet at this time.

Plants, mostly juniper berries, were found in scats from all seasons. These berries were abundant on most watersheds during fall, winter, and spring, and their availability was reflected in the diet from September through May. Birds were most prevalent in the diet in summer and fall. Reptiles were least abundant in scats during winter, when reptiles were hibernating, and were found most frequently during spring and summer. Arthropods were consumed most often throughout spring and summer and were found in $49.5 \%$ of both the spring and summer scats. An increase in the variety of food categories used within all the major groups in the early fall is probably due to increased energy requirements as young predators are attaining adult size, as well as to the availability of the foods.

Among mammalian foods, rodents were the most frequent in Beaver Creek carnivore scats. The Abert squirrel was the most frequent sciurid. Rock squirrels were consumed in large numbers. Golden-mantled ground squirrels were also important foods when not in hibernation. The presence of this ground squirrel and a chipmunk in the winter diet suggests that these rodents may sometimes be taken when hibernating.

Meadow mice and white-footed mice were the main mammalian foods of forest carnivores. They were frequent in the diet throughout the spring, summer, and fall. Woodrats were in $4.0 \%$ of the droppings throughout warmer months, but none were found in winter scats. There were fewer rabbits and hares in the diet than expected (5.4\%). There were also fewer rabbits and hares in carnivore diets on the study area than in most locations. The increased incidence of mule deer in Beaver Creek carnivore diets in summer months was apparently due to increased fawn consumption, as evidenced by the many hoofs contained in the scats.

Reptiles apparently were not taken in relation to their availability. Fence lizards were the most frequent reptile in the diet and were found mostly in the spring and fall. Lizards were found three times as often as snakes were. Another prey source which apparently was not used to its fullest was the leopard frog, which was abundant in many of the stock-watering tanks on the Beaver Creek area. Fish remains were found in three spring scats.

Arthropods were found in the diet during 11 months but were taken most frequently in the spring and the summer. That there were arthropods in $10.6 \%$ of the winter scats again indicates some carnivores apparently dig beneath the snow to obtain food.

Grasshoppers and crickets were frequent food items. Many scats contained the remains of at least ten grasshoppers. Beetles were also frequent. Many beetles, such as darkling beetles, are large; and, since they were taken frequently, they were probably an important source of energy. Grasses were eaten throughout the year. Their consumption may function in scouring parasites from the alimentary tracts of predators.

As indicated by the average number of food types per scat for each season, dietary variability reflected the abundance of the kinds of foods available in the habitat. Beaver Creek carnivores ate the fewest kinds of items during winter months. For the canines (coyotes and gray foxes), dietary variability was lowest in winter, increased progressively through spring, and then was greatest during the June-August period. September-November scats indicated a decrease in the number of taxa taken by these canines. Coyote variability ranged from an average of 1.7 to 2.7 food types per scat. The number of gray fox food types varied from 1.3 per scat during winter to 3.5 during the summer months. The greatest number of food types per coyote scat was five from a summer sample, as it was for gray foxes. The number of taxa consumed by bobcats was similar during the spring, summer, and fall seasons, averaging from 2.1 to 2.3 per scat with a summer dropping and a fall sample each containing representatives of six taxa.

\section{Coyote Food Habits}

A total of 55 coyote scats were analyzed. Considering major food categories for the entire study period, there were mammals in $67.3 \%$ of the droppings. Meadow mice were the most frequent rodents, though squirrels were also important. Deer and elk also were frequent in the diet, being found in $16.4 \%$ and $9.1 \%$ of the scats, respectively. Birds, mostly Passeriformes, were in $1.8 \%$ of the scats. Plants and arthropods were in $74.5 \%$ and $36.4 \%$ of the scats, respectively. Plants were mostly juniper berries and grasses. Lizards were the only reptiles in the diet, and were in $5.5 \%$ of the droppings.

Analyses of seasonal food item frequencies (3-month periods) indicated that during the winter coyote diets consisted mainly of juniper berries and mammals, mostly deer and elk. Deer were present in $27.2 \%$ of the winter scats, elk in $18.1 \%$. Meadow mice and whitefooted mice were the only rodents found during the December-February period. The presence of a lizard in one winter sample, and of arthropod remains in $9.0 \%$ of the winter scats, indicates that coyotes may dig beneath and snow and into the ground (or perhaps in rotting logs) to obtain foods. The December-February period had the least variation in kinds of food categories consumed by coyotes.

March-May diets were generally similar to those of winter months, but warmer weather apparently in- 
creased the availability of some foods. Insect consumption increased during this season as did the frequency of reptile foods. Arthropods were in $66.7 \%$ of the coyote scats. Juniper berries were found in $75.0 \%$ of the droppings. Other items found equally in spring coyote scats were cottontails, squirrels, white-footed mice, antelope, and birds $(8.3 \%)$. There were decreases in frequency of deer and elk. A scarcity of rodents was also evident in coyote diets at this time.

Coyote food habits were the most varied in the summer, including 17 taxonomic categories. Again, arthropods were an important item, being found in $60.0 \%$ of the scats. The summer reproductive seasons of small mammalian species increased their availability as prey items; white-footed mice, meadow mice, and woodrats made up a large portion of the summer diet. Rabbits, ground squirrels, and tree squirrels in the diet also increased over the previous season. Juniper berries continued to be available, but consumption declined and these were represented in $53.3 \%$ of the summer scats.

September-November scat contents were less varied. Field observations indicated that juniper berries were at their peak availability at this time. They were represented in $76.5 \%$ of coyote fall scats. Collectively, mammals were a large portion of the diet during this period. Deer fawns were still available and contributed to $23.5 \%$ of the fall scats. Lowering temperatures during this season probably caused the reduction in the number of arthropods consumed by coyotes.

\section{Gray Fox Food Habits}

One hundred gray fox scats were analyzed. Plants were found in $67.0 \%$ of the scats, mammals in $38.0 \%$, bird remains in $9.0 \%$, reptiles in $2.0 \%$, and arthropods $52.0 \%$. Juniper berries were important to the overall diet, with $55.0 \%$ of the fox scats for the entire study period containing these fruits. Rodents were an important mammal contribution to fox diets, with squirrels and deer mice the most significantly abundant species within this group.

Seasonal analyses indicated juniper berries in $89.5 \%$ of the December-February fox scats. Deer and antelope were each contained in $10.5 \%$ of the winter scats. Presumably most of these were carrion. Since most fawns are well grown by winter, it is unlikely a fox weighing 12 pounds or less could successfully prey upon a juvenile or adult animal. A few ground squirrels were taken during the winter months. Apparently many of these prey animals were in hibernation. Meadow mice were the only other rodents in gray fox diets during the winter.

March-May gray fox scats had a juniper berry frequency of $73.5 \%$. Arthropods were in $47.1 \%$ of the spring scats. Mammalian foods also were more abundant than in the previous season; $20.5 \%$ of the scats contained remains of white-footed mice. Consumption of cottontails was also greater during this season than in winter. Woodrats were in a few of the summer scats also.

Gray fox diets continued to increase in variability during summer months. Insect consumption increased to an $87.5 \%$ frequency, while juniper berry frequency decreased to less than $13 \%$. Rabbits were an important food. The summer diet contained a variety of rodents, including golden-mantled ground squirrels, chipmunks, white-footed mice, woodrats, and meadow mice. Birds also contributed to the diet; $20.8 \%$ of the summer scats contained feathers. The tree climbing abilities of gray foxes probably alowed them to take young birds from the nest, as evidenced by the pin feathers detected in some scats.

Fall gray fox diets were similar to summer diets in the number of taxa represented. Arthropods decreased in September-November to a frequency of 56.5. Conversely, juniper berry consumption increased, reaching a frequency of 43.5 . White-footed mice and meadow mice each were in $13 \%$ of the fall scats. The use of these rodents by foxes was probably a reflection of their increased abundance as a result of the summer reproductive season.

\section{Bobcat Food Habits}

A total of 67 bobcat scats were examined in the study period. Mammals were found in $88.1 \%$ of all these scats, birds in $11.9 \%$, reptiles in $6.0 \%$, arthropods in $25.4 \%$, and plants in $17.9 \%$ of the samples. The more carnivorous diet characteristic of most felines was reflected in the foods of Beaver Creek bobcats. Rodents as a group probably were the major part of the bobcat diet; rodent species were represented in scats throughout the study period. Deer, insects, meadow mice, and cottontails were important foods. Unlike the canines, bobcats consumed few juniper berries.

Apparently few bobcats use the Beaver Creek ponderosa pine habitats during winter, as evidenced by low track counts in the snow and by the absence of winter bobcat scats. Spring food habits of bobcats reflected the return of deer to ponderosa habitats from lower elevations. Meadow mouse remains were found in $30.0 \%$ of the droppings during this period. Tree squirrels and ground squirrels were taken, and arthropods contributed to $40.0 \%$ of the March-May scats. Rabbits and woodrats were also important foods. Thirteen taxonomic categories were represented in bobcat spring diets.

Twenty categories were represented in bobcat diets during the summer. Arthropods were in $25.7 \%$ of the scats, deer remains in $31.4 \%$, and elk in $5.7 \%$. Rabbits were also an important item, with jackrabbits and cottontails combined being found in over one-fifth of the scats. Rock squirrels were in $14.2 \%$ of the droppings. Over $11 \%$ of the samples contained Abert squirrels. Similar frequencies of birds were evident.

Bobcat fall diets were similar to those of summer. Deer at a $45.5 \%$ frequency continued to be an important food. Cottontails, birds, and arthropods were all 
$18.2 \%$. Declines in woodrat and meadow mouse populations were reflected in fall bobcat diets when compared to the items consumed in summer.

\section{Diets of Other Carnivores}

The small sample and uneven seasonal distribution of black bear, mountain lion, striped skunk, and raccoon scats placed limitations on interpretations of the food habits of these species.

Only two scats from black bears were found in ponderosa habitat; one contained juniper berries, the other unidentified small fruits. Scats of small carnivore species were obtained mostly from live-trapped animals. Ten raccoon scats from the Beaver Creek area indicated an $80 \%$ frequency of juniper berries, $10 \%$ of grasses. Arthropods were evident in $30 \%$ of the scats. Lizard remains were in one raccoon dropping, and fish scales occurred in two scats.

A single mountain lion dropping contained mule deer, Abert and red squirrel remains, and a few juniper berries. Striped skunks contributed six scats, each of them containing insects. A white-footed mouse and juniper berries each were in one of these skunk scats.

\section{Use of Beaver Creek Areas by Carnivores}

Use of the ponderosa pine watershed areas by carnivore species was estimated by application of several methods: for spring, summer, and fall seasons, the number of scats that accumulated per mile of road in each area was determined (scats per mile); during winter, the number of identified sets of tracks in snow was counted to give tracks per mile detected by the observer; the diets of carnivore species were examined for each area, and the number of food items consumed was compared to the general availability of the food items on each area.

Scat collections on watershed roads during each month from May through October resulted from about 61.5 miles driven on the treated watersheds and over 39.5 miles driven on adjacent untreated areas. There was an average of 9.1 carnivore scats per mile on the treated watersheds and 8.7 scats per mile on the untreated check areas. Comparison of overall predator use with prey availability indicated that WS 10 and the control watershed had the greatest overall predator use. Squirrels, cottontails, and turkeys were important carnivore foods during winter months, as were juniper berries.

The preference for watershed areas shown by large carnivores during warmer months was also examined by obtaining selection indices. These were determined by dividing the average percent of tracks encountered per mile traveled by the number of watershed miles traveled. Use of the areas by coyotes was related to food base abundance, which was estimated by trapping and field observations. They used the untreated area adjacent to WS 10 most often during the warmer months, as indicated by the number of scats per mile of road. This watershed and the surrounding area had the greatest number of juniper trees and also rated highest in cottontail abundance. WS 12 and adjacent areas also rated high in coyote preference as well as in arthropod, cottontail, and deer abundance during the summer.

Gray foxes preferred WS 10 and the surrounding area during early summer, perhaps because juniper berries were abundant there at this time. They also preferred WS 12 where slash was windrowed. This area scored high in rodent numbers. There were many white-footed mice in the early summer fox diet. The control watershed was preferred in late summer probably because of the abundance of rodents and arthropods. The area adjacent to WS 17 also was used frequently by gray foxes. Trees on this watershed were heavily thinned with the slash piles left. The area had an abundance of grasshoppers and high populations of rodents in late summer.

In early summer bobcats preferred the control watershed (which was a high deer and elk density watershed), and they also indicated some preference for the adjacent WS 14. During late summer, WS 12 was most important to bobcats.

\section{Winter Use of Watersheds by Carnivora}

Predator use of Beaver Creek ponderosa pine habitats and the availability of prey were determined by walking or driving transects over the watershed areas soon after snowfall and recording the numbers of sets of tracks observed per mile. Track counts were made during December and January, and a total of 16.4 linear miles was traveled on the study areas.

Prey species were most available on WS 10, WS 12 , and WS 13 during the winter. Most of the tracks observed in snow on all watersheds were small rodents, turkeys, and squirrels. Except for a single elk track on WS 12, ungulate tracks were not observed on any watersheds during the winter.

The abundance of tracks on each watershed indicated coyotes and gray foxes used the Beaver Creek ponderosa pine habitats more than most carnivores during the winter. The control watershed had the highest coyote use, and WS 10 and WS 12 were also important to these species. Gray foxes preferred WS 10 and WS 17. The greatest abundance of small rodents was on WS 17. The abundance of rodents in and adjacent to slash piles on these areas was probably a factor in attracting these predators. The abundance of juniper berries on WS 10 was also probably an important factor in influencing gray fox and coyote use of that area. The greatest density of carnivore tracks per mile was recorded for gray foxes on WS 10 . Concentrations of up to 20 tracks per linear mile of transect were found on this area. Coyotes were second in the total density of tracks recorded on an area (10 per mile) which occurred on the adjacent area.

The only bobcat tracks detected on winter transects were on the control watershed. This activity, recorded in January, appeared to be the tracks of a single bob- 
cat. Bobcat tracks (all probably from one animal) were also observed on WS 8 during December. Apparently bobcats migrate to lower elevations during winter months. Lack of winter bobcat scats detected in ponderosa pine habitat added further evidence to this supposition.

\section{Discussion}

Analyses of scats from ponderosa pine habitat indicated the general, seasonal, and specific feeding patterns of carnivores. Predator food consumption is the result of interactions between many complex environmental conditions and is not always easily explained. However, it appears that as in most parts of their ranges, carnivores in the ponderosa pine type are opportunistic feeders, using foods that are locally or seasonally available. This relationship to food availability was reflected in the seasonal changes of the use of each major food group. The importance of any food item at a particular time is probably also affected by its abundance in the habitat in relation to all other food items. Behavioral changes caused by reproductive seasons, responses to climatic conditions and other factors determine the vulnerability of prey species. Mammals were most frequent in the diet from May through October, when their activity and reproduction levels were high. These vertebrates were consumed less from December through March, when their numbers and activity levels were reduced or the animals were in hibernation.

The increased consumption of deer by coyotes and bobcats during the fawning season in July may be because fawns were easily attainable. Concealment is their primary defense method during the first few weeks after birth. When fawns were larger and less susceptible to predation, juniper berries were ripe, and most predators shifted to eating them and the available insects. Cold weather in mid-October eliminated insects as a major energy source and again probably caused increased pressure on predators to obtain other foods. Even with deer, rodent, and insect populations declining at this time, the canines were apparently able to adapt and use juniper berries as a "buffer food" until more easily obtained foods were again available.

As is the case in most carnivores, diets were most varied when energy demands increased during the denning season in spring and early summer. Availability could have been the only reason birds were taken more frequently from March to June, but they did not appear as important when the carnivores were not rearing young. Other foods were taken in higher frequencies when carnivores were raising young and were otherwise taken in lower frequencies. As expected, reptiles and arthropods were most abundant in the summer diet and were rarely taken during the colder months when they were dormant.

Studies on captive animals indicate that diets of the more versatile predators, such as coyotes and gray foxes, reflect environmental conditions and prey availability more than food preferences. Gray foxes apparently were highly adaptable to winter conditions in the ponderosa pine habitat as they had the most varied diet among the Beaver Creek carnivores during this season. This probably explains why they were apparently the most abundant carnivore in the ponderosa pine habitats in winter. Their ability to subsist on a winter diet consisting of a large portion of juniper berries is apparently a key to this adaptability. Bobcats were more carnivorous and relied mostly on mammalian foods and apparently sought to avoid unfavorable habitats as indicated by their inactivity in ponderosa pine habitats during winter.

In addition to reducing prey availability, heavy snowfall apparently restricts bobcat movements. The combined results of heavy snow may have caused bobcats to retreat from higher ponderosa pine areas. McCord (1974) concluded that deep snow restricted bobcat movements. He noted that bobcats walked normally in snow less than 6 inches deep; but when they entered a drift above that depth, they retreated and circled it or bounded through it. Marston (1942) found that movement of bobcats was restricted in snows above about 7 inches deep. Nellis and Keith (1968) and Haglund (1966) also suggested that snow consistency was an important factor in the ability of bobcats to capture prey. During winter most Beaver Creek predators used plowed roads for travel when they were available but would occasionally take tangential courses to visit brush piles or small tree stands, apparently to investigate them for the presence of prey. Winter use of roads probably conserves energy by reducing the effort of walking in deeper snow. Of course, availability of food was probably also an important factor in habitat selection during winter. Raccoons and badgers were relatively inactive during winter months, as indicated by the scarcity of their tracks and droppings. A single set of fresh tracks of each of these species was observed in snow on a warm and sunny afternoon.

In addition to sharing certain qualities such as opportunism, Beaver Creek carnivores also showed features which were characteristic of each of their species throughout their ranges. For example, some niche specialization was evidenced by the bobcats on the study area. The bobcats relied heavily on whitefooted mice and meadow mice as a major food source, as this species does in many other habitats. In addition to food habits, behavioral patterns (indicated by tracking Beaver Creek predators in snow) were also species specific. Methods of marking scent posts, digging, and other behavioral traits followed rigid patterns characteristic of each species.

It was not determined how many deer and elk taken by Beaver Creek carnivores were carrion. However, in winter, carrion could have made large contributions to the fecal samples examined, as evidenced by an elk calf carcass that was used by gray foxes for several months after it was placed in a dump ground. On one portion of the study area, WS 12, deer and elk made up 
a large portion of the bobcat diet. McCord (1974) found that the high frequency of deer in scat samples of Massachusetts bobcats was the result of predation and not scavenging on carcasses, and Marston (1942) also found bobcats killed most deer they consumed. However, other authors reported deer eaten by bobcats usually were carrion (Hamilton and Hunter 1939, Rollings 1945, Pollack, 1951, Erickson 1955).

If it were determined that the large number of fawns eaten by bobcats on WS 12 were taken by predation, it appears that predator control could be effective in this watershed for increasing deer fawn and elk calf survival. The deer and elk probably were attracted to the cover, and perhaps the food available on windrowed slash in WS 12. Thus, in an area known to be a traditional fawning or calving ground, a selective control program for predators would probably enhance survival and thus increase ungulate populations in the surrounding suitable habitats.

\section{Literature Cited}

Chew, R. M., B. B. Butterworth, and Richard Grechman. 1959. The effects of fire on the small mammal populations of chaparral. Journal of Mammalogy 40:253.

Cook, Sherbourne F., Jr. 1959. The effects of fire on a population of small rodents. Ecology 40:102-108.

Erickson, A. W. 1955. An ecological study of the bobcat in Michigan. M.S. thesis, 133 p. Michigan State University, East Lansing.

Gier, H. T. 1957. Coyotes in Kansas. Kansas Agricultural Experiment Station Bulletin 393, 95 p. Manhattan.

Goodwin, John. 1975. Population densities and food selection of small rodents in Arizona ponderosa pine forests. M.S. thesis, 72 p. University of Arizona, Tucson.

Haglund, B. 1966. Winter habits of lynx (Lynx lynx L.) and wolverine (Gulo gulo L.) as revealed by tracking in snow. Viltrevy 4:81-310 [Swedish with English summary].

Hall, E. R., and K. R. Kelson. 1959. The mammals of North America. 2 volumes. 1,083 p. Ronald Press Co., New York, N.Y.

Hamilton, W. J., Jr., and R. P. Hunter. 1939. Fall and winter food habits of Vermont bobcats. Journal of Wildlife Management 3:99-103.

Lauckhart, J. Burton. 1956. The food of predaceous animals in N.E. United States. Pennsylvania Game Commission Report 1, 69 p. Harrisburg.

Lawrence, George E. 1966. Ecology of vertebrate animals in relation to chaparral fire in the Sierra Nevada foothills. Ecology 47(2):278-291.

LoBue, Joseph, and Rezneat M. Darnell. 1959. Effect of habitat disturbance on a small mammal population. Journal of Mammalogy 40:425-437.

Marston, M. A. 1942. Winter relations of bobcat to white-tailed deer in Maine. Journal of Wildlife Management 6:328-337.
McCord, Chet M. 1974. Selection of winter habitat by bobcats (Lynx rufus) on the Quabbin Reservation, Massachusetts. Journal of Mammalogy 55:428-437.

McCulloch, Clay Y. 1962. Watershed and game management. Arizona Watershed Proceedings 6:25-27.

McCulloch, Clay Y. 1963. The influence of pinyonjuniper eradication upon wildlife species. p. 117-142. In Wildlife research in Arizona: 1963. Arizona Game and Fish Department W78R8-WP5-J3. Phoenix.

McCulloch, Clay Y. 1965. Pinyon-juniper eradication. p. 189-220. In Wildlife research in Arizona: 1964. Arizona Game and Fish Department W78R9-WP5-J3. Phoenix.

McCulloch, Clay Y. 1966. Pinyon-juniper control and deer. Wildlife Views 13(2):11-13.

Murie, O. J. 1946. Evaluating duplications in analysis of coyote scats. Journal of Wildlife Management $10: 275-276$.

Murie, O. J. 1954. A field guide to animal tracks. The Peterson Field Guide Series 9, 374 p. Houghton Mifflin Co., Boston, Mass.

Nellis, C. H., and L. B. Keith. 1968. Hunting activities and success of lynx in Alberta. Journal of Wildlife Management 32:718-722.

Pollack, E. M. 1951. Food habits of the bobcat in the New England states. Journal of Wildlife Management 15:209-213.

Reynolds, Hudson G. 1964. Elk and deer habitat use of a pinyon-juniper woodland in southern New Mexico. North American Wildlife Conference 29:438-444.

Rollings, C. T. 1945. Habits, foods and parasites of the bobcat in Minnesota. Journal of Wildlife Management 9:131-145.

Scott, Thomas G. 1941. Methods and computation in fecal analysis with reference to the red fox. Iowa State College Journal of Science 15:279-285.

Scott, Thomas G. 1943. Some food coactions of the northern plains red fox. Ecological Monographs 13:427-479.

Turkowski, Frank J. 1969. Food habits and behavior of the gray fox (Urocyon cinereoargenteus) in the lower and upper Sonoran life zones of southwestern United States. Ph.D. thesis, 123 p. Arizona State University, Tempe.

Turkowski, Frank J., and Hudson G. Reynolds. 1970. Response of some rodent populations to pinyonjuniper reduction on the Kaibab Plateau, Arizona. Southwestern Naturalist 15:23-27.

Turkowski, Frank J., and Ross K. Watkins. 1976. Whitethroated woodrat (Neotoma albigula) habitat relations in modified pinyon-juniper woodland of southwestern New Mexico. Journal of Mammalogy 57(3):586-590.

Wood, John E. 1952. The effects of agriculture (ranching and farming) on the habitat and food supply of furbearers in the post oak region of Texas. p. 427-437. In Transactions of the 17th North American wildlife conference [Miami, Fla., March 17-19, 1952]. 
Wood, John E. 1954. Food habits of furbearers of the upland post oak region in Texas. Journal of Mammalogy 35:406-415.
Wood, John E., David E. Davis, and E. V. Komarck. 1958. The distribution of fox populations in relation to vegetation in southern Georgia. Ecology 39(1):160-162.

\section{Appendix}

\section{Flora List}

Arizona fescue

Blue grama

Clover

Geranium

Gambel oak

Junegrass

Juniper

New Mexican locust

Mountain muhly

Peavine

Ponderosa pine

Quaking aspen
Festuca arizonica

Bouteloua gracilis

Trifolium spp.

Geranium spp.

Quercus gambelii

Koeleria cristata

Juniperus spp.

Robinia neomexicana

Muhlenbergia montana

Lathyrus spp.

Pinus ponderosa

Populus tremuloides

\section{Fauna list}

Abert squirrel
Badger
Beetles
Black bear
Bobcat
Chipmunk
Coyote
Cottontail rabbit
Crickets
Elk
Grasshoppers
Golden-mantled
ground squirrel
Gray fox
Jackrabbit
Leopard frog
Long-tailed weasel
Mountain lion
Mule deer
Pronghorn antelope
Raccoon
Rock squirrel
Red squirrel
Striped skunk
White-footed mouse
Wild turkey
Woodrat

Sciurus aberti

Taxidea taxus

Coleoptera spp.

Ursus americanus

Felis rufus

Eutamias spp.

Canis latrans

Sylvilagus audubonii

Gryllidae spp.

Cervus elaphus

Locustidae spp.

Spermophilus lateralis

Urocyon cinereoargenteus

Lepus californicus

Rana pipiens

Mustela frenata

Felis concolor

Odocoileus hemionus

Antilocapra americana

Procyon lotor

Spermophilus variegatus

Tamiasciurus hudsonicus

Mephitis mephitis

Peromyscus leucopus

Meleagris gallopavo

Neotoma spp. 


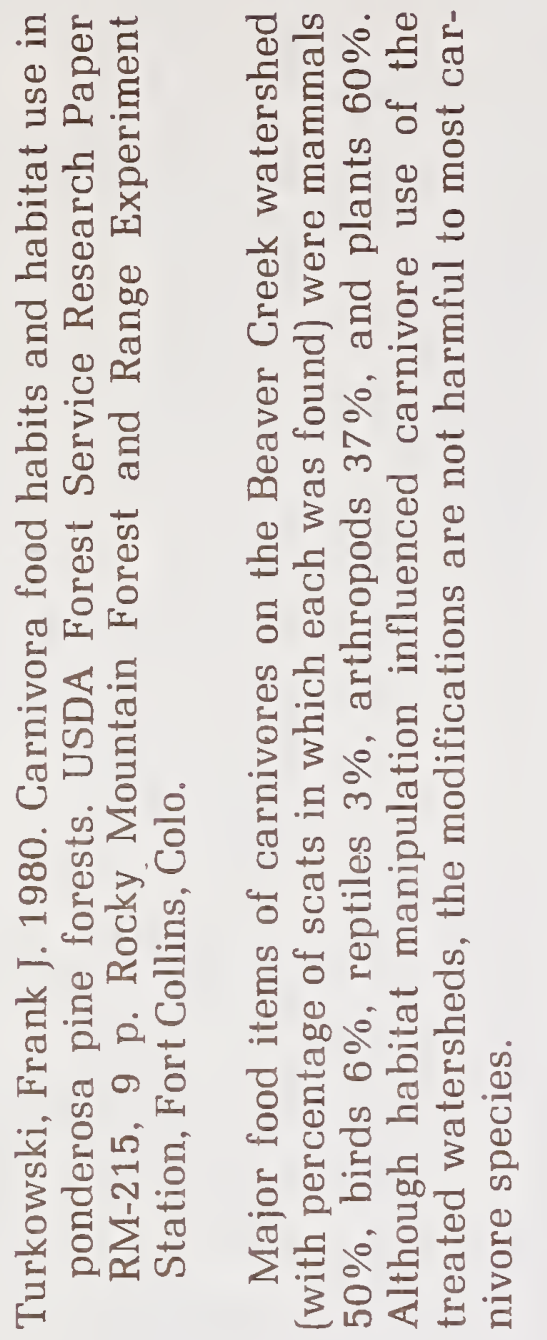

हี

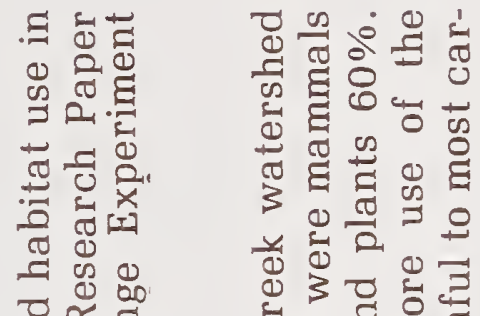
ฮี ฮี

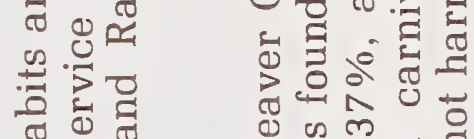
政

范

$\pi$

.

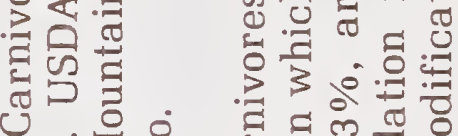

ข क ले

0 क

选造㐘

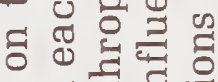

o

$\dot{\sim} 0$ 幽

光.

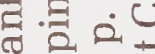
क

क्ष० है क

$\stackrel{0}{=} 0$.

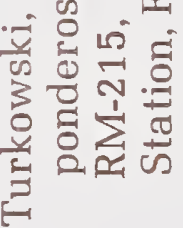

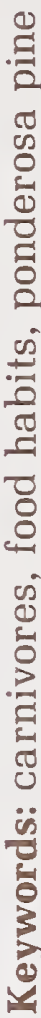

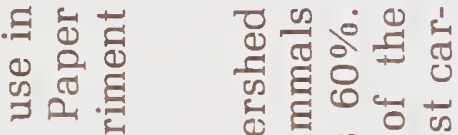

हैं

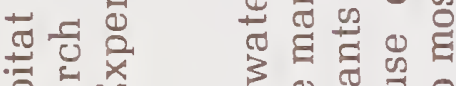

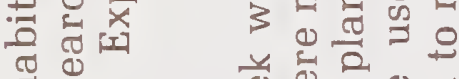

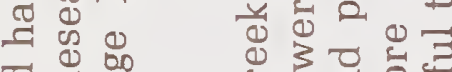

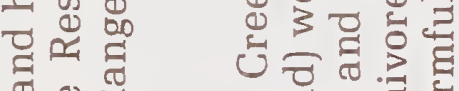

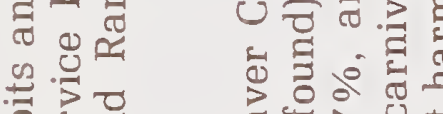

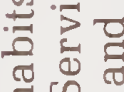

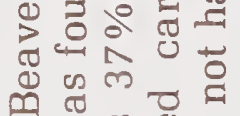

पु

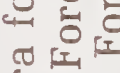

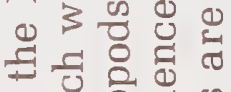

क⿺辶斤

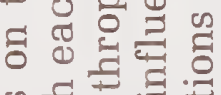

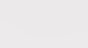

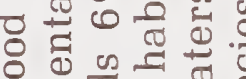

4.

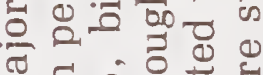

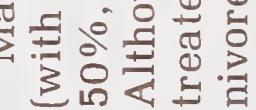

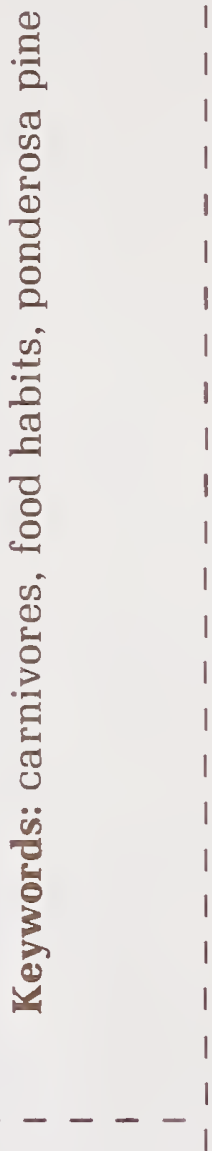

元豞泀

क 덩 ․ㅗㄹ

ㅇํㄹ

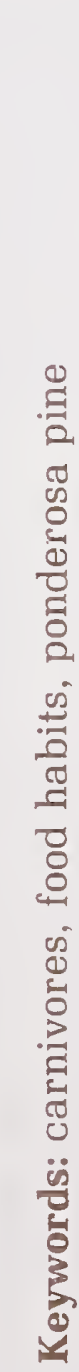

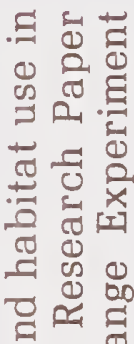

ช

$\stackrel{0}{0}:$

๘્ฮู

퓨

언도

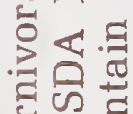

๑

घे के छ

$\infty$ क

ช

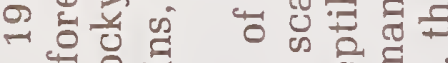

ㅇำ

考.

है

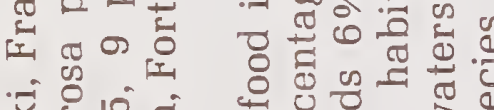

$\stackrel{0}{\infty} 0 . \frac{\pi}{\pi} \frac{0}{\pi}$

粦造 10

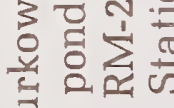

承

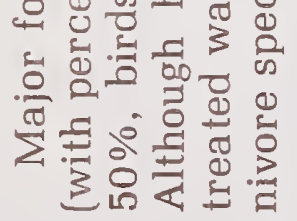

สำ

$\dot{0} \dot{0} \frac{0}{0}$

$0 \operatorname{lis}^{\circ} 0$

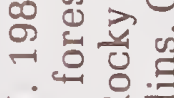

$\therefore$ 幽贾

है.

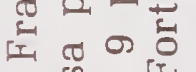

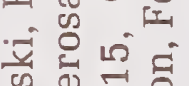

कै

䊑范范

坣

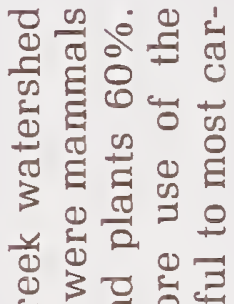

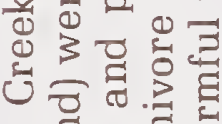

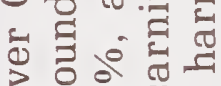

त्रेण

ติ के के

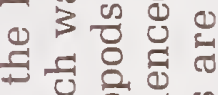

ธี

क 등

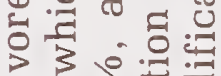

ज्ञ ते च्च

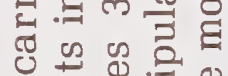

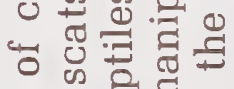

क 4

D 000

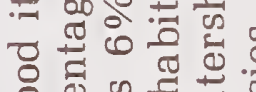

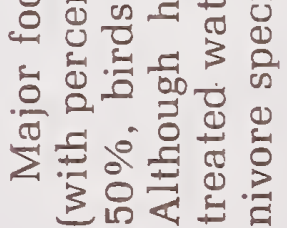

हี 


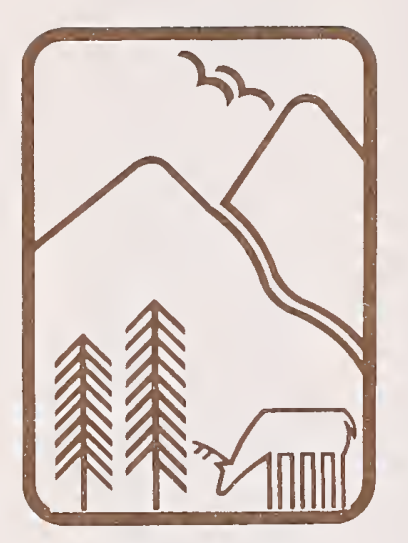

Rocky
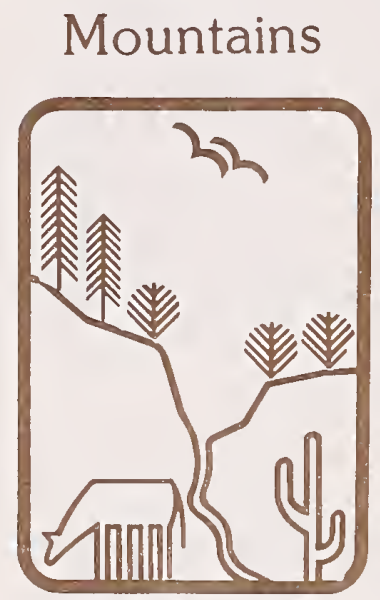

Southwest
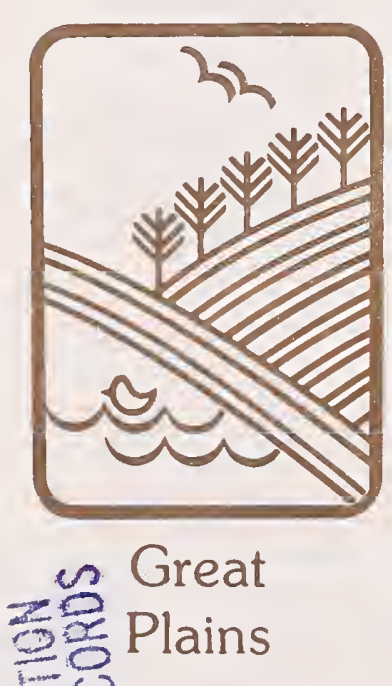

\section{U.S. Department of Agriculture Forest Service \\ Rocky Mountain Forest and Range Experiment Station}

The Rocky Mountain Station is one of eight regional experiment stations, plus the Forest Products Laboratory and the Washington Office Staff, that make up the Forest Service research organization.

\section{RESEARCH FOCUS}

Research programs at the Rocky Mountain Station are coordinated with area universities and with other institutions. Many studies are conducted on a cooperative basis to accelerate solutions to problems involving range, water, wildlife and fish habitat, human and community development, timber, recreation, protection, and multiresource evaluation.

\section{RESEARCH LOCATIONS}

Research Work Units of the Rocky Mountain Station are operated in cooperation with universities in the following cities:
Albuquerque, New Mexico
Bottineau, North Dakota
Flagstaff, Arizona
Fort Collins, Colorado*
Laramie, Wyoming
Lincoln, Nebraska
Lubbock, Texas
Rapid City, South Dakota
Tempe, Arizona 